\title{
PARTICIPAÇÃO, PROTAGONISMO E APRENDIZAGEM NA FALA-EM-INTERAÇÃO DE SALA DE AULA EM UMA EQUIPE DE TRABALHO NO ENSINO MÉDIO
} IN A CLASSROOM TALK-IN-INTERACTION WITHIN A HIGH SCHOOL WORKING TEAM

\author{
Rafael Petermann* \\ Instituto Federal do Paraná - IFPR \\ Paranavaí - Paraná / Brasil \\ Neiva Maria Jung ${ }^{* *}$ \\ Universidade Estadual de Maringá - UEM \\ Maringá - Paraná / Brasil
}

\begin{abstract}
RESUMO: Neste artigo temos como objetivo reconhecer protagonismo e agentividade no trabalho de fazer aprendizagem em dados de fala-em-interação da pesquisa de mestrado de Petermann (2016) realizada em um colégio privado no Paraná que funciona por meio de projetos temáticos de aprendizagem. A perspectiva epistemológica é a da Análise da Conversa Etnometodológica (LODER; JUNG, 2008, 2009; SACKS; SCHEGLOFF; JEFFERSON, 2003). Como resultado os dados apontam para uma nova ordem comunicativa de sala de aula que amplia as possibilidades de participação, agentividade e protagonismo na construção conjunta de conhecimento.
\end{abstract}

PALAVRAS-CHAVE: fala-em-interação; participação; protagonismo; aprendizagem.

\footnotetext{
*rafael.petermann@ifpr.edu.br

**neiva.jung@gmail.com
} 
ABSTRACT: In this paper, we aim to recognize the protagonism and agentivity in the learning activity in talk-in-interaction data of Petermann's master's research project (2016) held at a private high school in Paraná, which works with thematic learning projects. Our epistemological perspective is Ethnomethodological Conversation Analysis (LODER; JUNG, 2008, 2009; SACKS; SCHEGLOFF; JEFFERSON, 1974). As a result, data point to a new communicative order in classroom that increases the possibilities of participation, agentivity and protagonism in the joint construction of knowledge.

KEYWORDS: talk-in-interaction; participation; protagonism; learning.

\section{Considerações iniciais}

Os resultados de avaliações de larga escala aplicadas no Ensino Médio, como o Exame Nacional do Ensino Médio (Enem) e o Programa Internacional de Avaliação de Estudantes (Pisa, na sigla em inglês), sempre ganham repercussão midiática por exporem a situação desse nível de ensino no Brasil. Em dezembro de 2016, por exemplo, os resultados do Pisa foram midiatizados de forma alarmante, como na matéria da Folha de São Paulo intitulada "Estagnado, Brasil fica entre os piores do mundo em avaliação de educação", apresentando o Brasil abaixo da quinquagésima posição entre os 69 países e territórios analisados pelo exame. Além disso, a reportagem a que nos referimos destaca, por meio da fala de Priscila Cruz, presidente do Movimento Todos pela Educação, que o grande desafio do país está na formação e valorização de professores.

Como trabalhamos com uma posição ontológica e epistemológica que concebe o uso da linguagem como ação social por meio da qual os sujeitos se constituem no mundo (CLARK, 2000), ratificam ou não papéis institucionais (DREW; HERITAGE, 1992) e negociam identidades sociais (GUMPERZ, 2013; GOFFMAN, 2013; JUNG, 2009), defendemos que avaliações em larga escala desconsideram as realidades escolares localmente situadas, pois apresentam simplesmente dados obtidos a partir de um olhar panorâmico, em que as mesmas provas são aplicadas para avaliar contextos escolares completamente diferentes, com realidades sociais e culturais muito distintas. Desse modo, para repensar políticas públicas para o Ensino Médio e ou práticas pedagógicas, essas devem(riam) ser precedidas por empreendimentos analíticos que se prestem a entender o que efetivamente está acontecendo no aqui-e-agora em uma sala de aula. Há muita política

${ }^{1}$ Disponível em: <http://bit.ly/2gCgUle>. Acesso em: 28 dez. 2016. 
educacional local e protagonismo estudantil que não são visibilizados por essas avaliações que, segundo Street (2014), se tornaram novas formas de governança global da educação.

Para além de problematizar avaliações em larga escala, queremos retomar os desafios apontados para a educação brasileira na reportagem referenciada anteriormente. Corroboramos o desafio de que precisamos valorizar os professores brasileiros, especialmente por meio de pagamentos justos, direito à hora-atividade para preparação das aulas, direito de ser ouvido em suas reivindicações, dentre tantos outros. O que queremos problematizar, no entanto, é o desafio apontado em relação à formação de professores, não como algo que coloque o professor como o vilão desses "resultados da educação brasileira", mas no sentido de reconhecer a estagnação de nossas formas de conceber o ensino e especialmente a aprendizagem escolar.

Considerando o avanço das novas tecnologias e as mudanças nas sociedades, em termos por exemplo das mobilidades das pessoas pelo mundo (BLOMMAERT; RAMPTON, 2011), dos novos formatos de textos, das translinguagens dos falantes (CANAGARAJAH, 2012; LUCENA, 2015), enfim, temos alunos contemporâneos em nossas salas de aula. Desse modo, o modelo de organização da sala de aula, no sentido de o professor gerenciar a tomada de turnos e ser aquele ratificado o tempo todo como o que sabe e precisa transmitir conhecimento já nem sempre tem sido coconstruído no aqui-e-agora dos espaços escolares. Há espaços com novas ordens comunicativas nas quais o termo "protagonismo" vai além do papel do discente nas mais diversas atividades do contexto escolar, como a organização política com os grêmios estudantis e o processo de ensino e aprendizagem (FERRETI et al., 2004). Rampton (2006) demonstrou, por exemplo, por meio de uma etnografia realizada em uma escola pública na periferia de Londres, que uma nova ordem comunicativa, avessa aos modelos canônicos de interação de sala de aula, acontecia naquele ali-e-então. Ele verificou ocorrências de aluno disciplinando aluno; aluno desafiando professor; cantorias; e verificou ainda que, por meio dessas atividades interacionais, os alunos mantinham a aula em curso.

Lopes (2015), por sua vez, em pesquisa etnográfica orientada por pressupostos da Análise da Conversa Etnometodológica, realizada em uma sala de aula de espanhol como língua adicional em uma escola pública de Porto Alegre, também observou um contexto em que aluno disciplinava 
aluno, aluno desafiava professor, alunos e professor compartilhavam o trabalho de fazer aula animada e também o trabalho de fazer aprendizagem e, segundo a pesquisadora, nesses empreendimentos interacionais conjuntos os participantes negociavam a pauta, mantinham a aula em curso e manifestavam sua identidade juvenil.

Esses estudos mostram que precisamos compreender como sujeitos inseridos em um contexto específico de sala de aula se constituem e são constituídos como aluno, professor e como coconstroem o trabalho de participar, aprender e ser protagonistas do próprio processo de aprendizagem no evento aula. Análises interacionais de como se dão os processos de coconstrução da participação e do protagonismo em sala de aula podem auxiliar na compreensão, em perspectiva micro, da organização política da sala de aula, desconstruindo mitos, como o de que estamos estagnados na educação, e apontando para zonas de atuação e mediação docente.

Dentro dessa problemática e a partir da perspectiva microetnográfica (ERICKSON; SHULTZ, 2013; GARCEZ, 2008b) e com base nos pressupostos teórico-metodológicos da Análise da Conversa Etnometodológica (LODER; JUNG, 2008, 2009; SACKS; SCHEGLOFF; JEFFERSON, 1974 [2003]), nos propomos a analisar e descrever um dado de fala-em-interação ${ }^{2}$, gerado no final de 2014. Nosso objetivo é revisitar este dado mostrando protagonismo e agentividade no processo de construção conjunta de conhecimento, no contexto analisado, por meio de oportunidades de participação menos assimétricas e mais democráticas.

Para tanto, na seção seguinte apresentamos breve discussão sobre a organização da fala-em-interação de sala de aula, destacando modos de organização canônicos, que contribuem para o controle social e a reprodução do conhecimento, e modelos não canônicos, que favorecem, por sua vez, a construção conjunta de conhecimento, o protagonismo e o engajamento. Em seguida, apresentamos os procedimentos metodológicos de geração de dados e, depois, analisamos um dado de fala-em-interação, demonstrando como os participantes são protagonistas da própria aprendizagem e constroem conhecimento em conjunto. Por fim, apresentamos as nossas considerações finais, sistematizando alguns resultados a partir da análise empreendida, e tentamos apontar para uma interlocução pedagógica.

\footnotetext{
${ }^{2} \mathrm{O}$ projeto de pesquisa que permitiu a coleta desses dados passou por avaliação e aprovação do Comitê de Ética da Universidade Estadual de Maringá; CAAE 38194114.1.0000.0104.
} 


\section{Organização da fala-em-interação em sala de aula: reprodução ou construção conjunta de conhecimento?}

Do ponto de vista da Análise da Conversa Etnometodológica (doravante ACE), base teórica a que nos afiliamos, a constituição da sociedade e de suas instituições se dá em grande medida pelas ações que os membros de cada grupo social executam ao usar a linguagem na falaem-interação (CORONA, 2009; GARCEZ, 2006). Desse modo, olhando especificamente para o cenário escolar, aquele que nos interessa, pode-se entender que o que constitui uma sala de aula não são elementos como paredes, janelas ou a disposição física do mobiliário, mas o que as pessoas fazem conjuntamente quando se encontram para fazer o que precisam e desejam fazer nesse espaço (GARCEZ, 2006), em outras palavras, uma sala de aula constitui-se à medida em que pessoas produzem ações conjuntas que demonstram que aquilo é uma sala de aula.

Para Markee e Kasper (2004, p.492; tradução de SCHULZ, 2007)³, a fala-em-interação de sala de aula é uma "conexão entre sistemas de trocas de fala inter-relacionados, e não como um sistema unificado caracterizado por um conjunto único de perguntas-respostas e comentários”. Para os autores não há, portanto, uma única organização da fala-em-interação de sala de aula, mas uma gama de falas de sala aula, que são avultadas à medida que há diversidade de práticas sociais dos sujeitos que se encontram engajados em um trabalho conjunto.

Corroboram essa afirmação trabalhos como o de Cazden (2001), que discute de que modo, no gerenciamento dos turnos na sala de aula, o professor pode selecionar o próximo falante, assim como pode optar por não o fazer; e os de Rampton (2006) e Lopes (2015), que defendem a existência de uma nova ordem comunicativa na chamada sala de aula contemporânea na qual os alunos podem realizar participações exuberantes (RAMP'TON, 2006), como cantar, fazer zoeiras e fazer riso.

Cabe salientar que embora certas rupturas com as formas de organização canônicas da fala-em-interação tornem a interação de sala de aula menos ritualizada, como é o caso que abordaremos neste artigo, não se pode falar que nesses contextos a institucionalidade inexista ou que se passou

\footnotetext{
${ }^{3}$ No original: “[...] Classroom talk as a nexus of inter-related speech exchange systems rather than as a unified speech exchange system that is characterized by a single set of question-answer-comment practices."
} 
a ter uma conversa cotidiana (GARCEZ, 2008a), pois nesses contextos ainda há uma meta-fim e a necessidade de o professor e/ou alunos organizarem-se por/para uma pauta.

Entendemos, portanto, que a fala-em-interação de sala aula pode ser genericamente caracterizada como um fazer conjunto orientado para uma pauta relacionada a uma tarefa, em que controle e gerenciamento das formas de participação são de responsabilidade de um dos participantes, em geral o professor, ou compartilhadas. Dessa forma, a organização e o gerenciamento da tomada de turnos e da participação em sala de aula podem se direcionar para sequências que primam o controle social e a reprodução de conhecimento; ou podem se direcionar para possibilidades mais democráticas da organização da fala, como o revozeamento e outras formas que variam conforme as diferentes demandas desse contexto. A seguir, apresentamos algumas formas já descritas de organização das interações de sala de aula.

\subsection{Iniciação-Resposta-Avaliação}

A sequência interacional denominada Iniciação-Resposta-Avaliação (IRA) é uma sequência de avaliação que se inicia com uma pergunta, seguida de uma resposta e, por fim, por um turno de avaliação. O exemplo adaptado de Garcez (2006, p.68) ilustra sua organização:

\begin{tabular}{|c|c|c|}
\hline & Marta: & que horas são? \\
\hline & Lucas: & duas e meia. \\
\hline & Marta: & muito bem. \\
\hline
\end{tabular}

Por se tratar de um modelo de organização da fala-em-interação de sala de aula praticamente universal (CAZDEN, 2001; GARCEZ, 2006, 2012), não seria difícil associar a sequência acima a uma sala de aula de Ensino Fundamental em que Marta aponta para um relógio diante dos alunos, seleciona Lucas como próximo falante e solicita a ele a informação. Cabe ressaltar que Marta, além de conhecedora da informação que solicitou para Lucas, também é a mais capacitada para organizar uma resposta diante da própria solicitação (GARCEZ, 2006, p. 68), por isso a sequência IRA geralmente legitima papéis institucionais (LOPES, 2015). Isso significa que a pergunta do turno de iniciação na sequência IRA tem a finalidade de verificar se os alunos sabem responder corretamente ao que se espera. Dessa forma, o iniciador e avaliador são identificados como o professor, aquele que sabe 
e que pode avaliar, pois já é conhecedor da resposta, assim "não se trata de uma pergunta qualquer, com que nos deparamos a todo momento na conversa cotidiana, e sim uma ação preliminar que só será levada a cabo plenamente no turno em terceira posição, de avaliação. "(GARCEZ, 2006, p.69).

Com efeito, considerar que na sequência IRA a iniciação é realizada a fim de que, depois da resposta, seja feita uma avaliação implica dizer que ela serve ao propósito de testar e perseguir uma resposta ideal, em geral, a do professor. Nesse sentido, quando a resposta esperada não é dada, o professor pode seguir com o turno, fazendo iniciações até que a resposta esperada seja conseguida, ficando "surdo" para outras respostas, fechando a sequência IRA apenas com a avaliação positiva (WARING, 2008).

Vale ressaltar que conforme aponta estudo realizado por Waring (2008) em uma sala de aula de língua inglesa como língua adicional nos Estados Unidos, ao avaliar positivamente a resposta de um aluno, o professor finaliza a sequência IRA e, consequentemente, inibe as demais participações de outros alunos. Assim, a crítica que recai sobre essa sequência é que, além de ser vista como uma forma econômica para se avaliar os alunos em sala de aula, também pode ser caracterizada como uma ação de controle social que reforça a assimetria entre professor e aluno e, por isso, as atividades geralmente produzidas nessa sequência (avaliar, testar, impor informações) dificilmente resultam em construção conjunta de conhecimento, pelo contrário, favorecem a reprodução de conhecimento. Além disso, conforme Garcez (2006, 2012), essa sequência também não contribui muito para formação de cidadãos participativos e críticos, uma vez que os espaços para participações e protagonismo do estudante no trabalho de construir conhecimento em conjunto são cerceados neste modo de organização interacional.

\subsection{Revozeamento e nova(s) ordem(ns) comunicativa(s) de sala de aula}

Cazden (2001) afirma que novos objetivos curriculares demandam diferentes formas de organização da fala, o que significa que professores, com repertórios variados de organização das aulas, podem organizá-las de modo a possibilitar momentos de construção conjunta de conhecimento. Assim, entendemos que não há uma fala-em-interação de sala de aula, mas, conforme já pontuaram Markee e Kasper (2004), falas (no plural) de sala de aula. 
Uma das formas de organização alternativas à IRA é o revozeamento, descrito por O'Connor e Michaels (1996, p.71; tradução de LOPES, 2015) como "um tipo particular de redizer (oral ou escrito) a contribuição do aluno - por outro participante da fala-em-interação". Nessa organização interacional de sala de aula, o professor reformula a contribuição do estudante para avaliação pelo próprio aluno ou por um colega, dando créditos à contribuição original do aluno. A seguir, reproduzimos excerto dos dados de Conceição e Garcez (2005, p. 5) gerado em uma Escola Pública Municipal de Porto Alegre a fim de ilustrar uma organização semelhante ao revozeamento.

$\begin{array}{lll}1 & \text { Silvia } & \text { ó o Flávio está dizendo que o porco (.) } \\ 2 & \text { fala Flávio } \\ 3 & \text { Flávio } & \text { ó o mais inteligente } \\ 4 & \text { Silvia } & \text { que o porco é o mais inteligente } \\ 5 & & (.) \\ 6 & \text { Silvia } & \text { o quê que vocês acham disso, }\end{array}$

Neste excerto, é possível perceber que Silvia, a professora, passa o turno para Flávio e rediz a contribuição dele (linhas 1 a 4). Em seguida, a torna objeto de reflexão e discussão dos estudantes a partir da formulação de uma pergunta de informação desconhecida e não seleciona o próximo falante (linha 6), o que abre espaço para que qualquer aluno se sinta autorizado para tomar o turno e fazer sua contribuição. Nesses termos, pode-se considerar que o revozeamento é um mecanismo capaz de gerar participações mais igualitárias e contribuir para a construção conjunta de conhecimento. (CAZDEN, 2001; CONCEIÇÃO; GARCEZ, 2005; GARCEZ, 2006, 2012).

No entanto, é preciso observar que, mesmo sendo considerado como uma forma de participação mais democrática, é o professor quem gerencia os turnos de fala dos alunos no revozeamento, por isso não se pode considerar que por si só ele seja uma estrutura que possibilita espaço para o protagonismo dos alunos. Segundo Schulz (2007), o que determinará o protagonismo é o uso local dessas formas.

\footnotetext{
${ }^{4}$ No original: "[...] a particular kind of reuttering (oral or written) of a student's contribution - by another participant in the discussion".
} 
Trabalhos recentes como os de Lopes (2015) e Rampton (2006), já mencionados neste texto, têm apontado para novos modos de participar na sala de aula que não se enquadram nos modelos convencionais, ou seja, têm apontado para o aparecimento de uma nova ordem comunicativa da falaem-interação de sala de aula contemporânea que engloba o novo modo de ser jovem na escola (DARYELL, 2003; LOPES, 2015).

Rampton (2006) realizou um estudo etnográfico em uma turma de nono ano em uma escola pública de Londres e demonstrou que nesse contexto os participantes podiam não legitimar na interação a conduta hierárquica tradicional da relação entre professor e alunos, não se limitando a falar quando o professor autorizava, questionando o professor, disciplinando outros alunos, autosselecionando-se, avaliando o professor. Tratava-se de uma ordem comunicativa em que o professor não era o único que regia as tomadas de turno e por isso precisava negociar interacionalmente seu papel social. Chama atenção no estudo de Rampton que os alunos que poderiam ser reconhecidos como perturbadores da ordem canônica da interação de sala de aula, eram os mais participativos, estando atentos a ponto de completar as falas do professor, disciplinar outros alunos e produzir participações exuberantes.

Lopes (2015) observou as participações não canônicas de alunos do Ensino Médio de uma escola pública brasileira em aulas de língua espanhola. A pesquisadora mostrou ocorrências de aluno disciplinando aluno, aluno corrigindo o professor, aluno desafiando o professor e aluno cantando em sala de aula. Conforme demonstrado na pesquisa, essas participações revelavam que os estudantes compartilhavam os trabalhos interacionais de fazer aula de língua espanhola e fazer aprendizagem ${ }^{5}$ simultaneamente, pois estavam orientados para um objeto de aprendizagem ${ }^{6}$, no caso a língua

\footnotetext{
${ }^{5}$ Pesquisas em ACE (ABELEDO, 2008; KANITZ, 2013; LOPES, 2015; UFLACKER, 2012, por exemplo), cujo foco analítico está nos métodos que os participantes de uma interação usam para produzir ação social conjunta, têm entendido que em contextos de sala de aula, quando os participantes estão orientados para o mesmo foco de atenção em torno de um objeto de aprendizagem, eles estão realizando o trabalho de fazer aula e fazer aprendizagem.

${ }^{6}$ Com base no uso do termo "objeto de aprendizagem" nos trabalhos de Abeledo (2008) e Lopes (2015), entendemos que este se trata de ponto/tópico/pergunta/dúvida, emergente e contingente na interação, para o qual os participantes se orientam e produzem ação social no intuito de construir um entendimento satisfatório que o encerra. Neste artigo, é essa a definição que também adotamos quando nos referimos a objeto de aprendizagem.
} 
espanhola, e estavam engajados em torno desse objeto produzindo as ações já mencionadas. Segundo a pesquisadora, os dados evidenciaram que na nova ordem comunicativa da sala de aula havia oportunidades para a participação e protagonismo no trabalho de fazer aprendizagem.

$\mathrm{Na}$ organização da fala-em-interação da sala de aula em que os dados para os quais olhamos neste artigo foram gerados, algumas das condutas observadas por Rampton (2006) e Lopes (2015) também são notadas, sobretudo a constante negociação dos participantes em torno de uma pauta. Difere, todavia, o contexto que analisamos, pelo fato de as políticas pedagógicas da instituição buscarem promover, por meio da organização dos alunos, essas condutas. Na próxima seção, apresentamos brevemente o contexto em que os dados foram gerados.

Nesta seção, procuramos abordar a fala-em-interação de sala de aula, apresentando algumas formas de organização em que a regência das falas fica a cargo do professor e outras não canônicas, como na nova ordem comunicativa da sala de aula contemporânea, que evidencia novas formas de participação e um deslocamento do papel do professor como o único organizador dos turnos e aquele que sabe.

\section{Percurso metodológico e contexto de geração de dados}

Os dados de fala-em-interação desta pesquisa foram gerados no último bimestre letivo de 2014 em uma sala de aula do Colégio Empreendedor ${ }^{7}$, escola privada situada no Paraná, por ocasião do trabalho de mestrado de Petermann (2016). Essa escola adota metodologia específica que prima pelo trabalho pedagógico em perspectiva interdisciplinar e pautado em projetos temáticos norteados por desafios de aprendizagem. A disposição física das salas de aula é constantemente formada por equipes com até seis alunos de diferentes séries do Ensino Médio, o que mostra outra faceta da metodologia da escola, a interseriação ${ }^{8}$. Além disso, o colégio não adota um material didático específico, mas os alunos trazem materiais diversos, como tablets, celulares, notebooks que podem utilizar para dar conta dos desafios propostos.

\footnotetext{
${ }^{7} \mathrm{O}$ nome da instituição em que os dados foram gerados, bem como dos participantes da pesquisa são fictícios a fim de se preservar a identidade dos sujeitos da pesquisa.

${ }^{8}$ A interseriação, no Colégio Empreendedor, consiste em alunos das diferentes séries do Ensino Médio trabalhando juntos, nas mesmas equipes e nas mesmas tarefas.
} 
O projeto temático que ocorria na época da geração de dados era intitulado $O$ que se põe à mesa. O desafio que norteava o trabalho das diferentes disciplinas era a discussão da mesa como local de refeições e encontros sociais. A atividade final deste projeto era a produção de uma pizza saborosa, nutritiva e sustentável, que seria produzida pelos próprios alunos e servida em uma mesa onde, além de se alimentarem, os alunos e professores promoveriam debate sobre várias questões dos cenários político, cultural, esportivo etc.

Os procedimentos que envolveram a geração dos dados foram: observação participante; registro audiovisual de uma das equipes de trabalho da sala; segmentação e transcrição seletiva dos dados segundo convenções de Jefferson (GAGO, 2002; LODER, 2008) e com base também em transcrição multimodal (GARCEZ; BULLA; LODER, 2014), conforme convenções em anexo.

Ao todo, foram feitas cerca de trinta horas de registro audiovisual da atividade interacional de uma das equipes de trabalho formada por seis alunos do Ensino Médio: dois da terceira série, Célia e Arthur; um da segunda, João; e três da primeira Taís, Laís e Lucas. Esses alunos e o professor Miguel são os participantes da pesquisa.

Para os fins deste artigo, selecionamos um segmento gerado em uma aula de história do professor Miguel. Entendemos que este é um exemplo representativo de nosso corpus de análise, tendo em vista os seguintes critérios: i) trabalho interacional bem marcado em torno de um objeto de aprendizagem; e ii) participação e engajamento de estudantes em determinada pauta, demonstrando protagonismo no trabalho de construir conhecimento em conjunto. Na seção seguinte, apresentamos o exercício analítico que empreendemos sobre o dado de fala-em-interação selecionado e discutimos como a participação e o engajamento na fala-em-interação são evidências de agentividade e protagonismo estudantis na aprendizagem.

\section{Fala-em-interação na sala de aula contemporânea: espaços para participação e protagonismo}

Pesquisas brasileiras em Linguística Aplicada se propuseram a discutir a aprendizagem como ação social, investigando cenários diversos e interpretando como se dão participação e aprendizagem. Nosso recorte e filiação aqui são com trabalhos produzidos na perspectiva da ACE, que analisaram dados de ocorrência natural de uso da linguagem, com “" [...] 
interesse etnometodológico em estudar a racionalidade prática cotidiana, o raciocínio sociológico dos agentes sociais enquanto agem e que fica evidente na sua conduta" (GARCEZ, 2008a, p. 22). Em especial, nos filiamos a pesquisas produzidas pelo Grupo de Pesquisa Interação Social e Etnografia, da Universidade Federal do Rio Grande do Sul, com destaque para a pesquisa de doutorado de Abeledo (2008), que é um dos trabalhos seminais brasileiros acerca de investigações sobre aprendizagem como ação social pela perspectiva da ACE.

Abeledo (2008) aponta para a ligação entre participação e construção conjunta de conhecimento. A pesquisadora analisa, na aula de língua espanhola em uma escola de idiomas, o trabalho de fazer aprendizagem de vocabulário. Ela mostra que o trabalho de aprender implica que os participantes tornem pública sua competência ${ }^{9}$ para participar de determinadas atividades em comunidades situadas, o que ocorre por meio da construção de conhecimento situado, sobretudo pela busca de superação de obstáculos para participar das ações da própria aula. Assim, Abeledo (2008, p. 6) formula uma compreensão etnometodológica de aprendizagem como:

Uma articulação pública, intersubjetiva, emergente e contingente, produzida para os fins práticos das atividades desenvolvidas em cada interação; (b) observável nos métodos que constituem o trabalho dos participantes para produzir essa realização, que não são generalizáveis, mas adequados a um contexto e a identidades que eles reflexivamente instauram - institucionais ou não -, e a objetos de aprendizagem que eles definem e tornam relevantes; e (c) que produz relações de participação e pertencimento, já que implica a produção pública e intersubjetiva de competência para participar em atividades levadas a cabo em uma comunidade.

Cabe destaque também, pela discussão que faz sobre participação e construção conjunta de conhecimento, a pesquisa de Kanitz (2013). Fora do contexto de sala de aula, porém ainda pensando na aprendizagem como ação social e em termos de construção conjunta do conhecimento, a pesquisadora observou um cenário de desenvolvimento tecnológico - laboratório de tecnologia voltado à produção de materiais biomédicos - em que a resolução

\footnotetext{
${ }^{9}$ Abeledo (2008, p. 169) define etnometodologicamente competência como a condição de membro competente de uma comunidade que é sustentada pelo uso da linguagem em interação para participar das atividades cotidianas de uma comunidade.
} 
de problemas e a busca por entendimentos para retomada de atividade suspensa pelo problema se constituem como instância interacional da construção conjunta de conhecimento. Os resultados da pesquisa apontam para o fato de que é "envidando esforços para a resolução dos problemas que os participantes constroem conhecimento com o outro". (KANITZ, 2013, p. 6)

Nesses dois trabalhos verificamos que, no processo de construção conjunta de conhecimento descrito, são pontos convergentes agentividade, participação e protagonismo dos estudantes, produzindo ação social orientada para objetos de aprendizagem que se tornam relevantes no aquie-agora da interação. Nesse sentido, para os fins analíticos deste artigo propomos, conforme Petermann (2016), que o trabalho de construir conhecimento conjuntamente compreende:

i) participação e engajamento dos interagentes ii) orientados para um objeto de aprendizagem tornado relevante no aqui-e-agora da interação iii) produzindo ação social em torno desse objeto, iv) demonstrando sua competência para participar, ratificando a participação dos demais e sendo ratificado v) a fim de dar conta dos fins práticos emergentes do objeto de conhecimento. (p. 43, grifos nossos)

Tendo em vista que construir conhecimento conjuntamente implica participação e engajamento na fala-em-interação orientada a um objeto de aprendizagem emergente e contingente de um aqui-e-agora; passamos à apresentação do exercício analítico que empreendemos a partir de um segmento interacional gerado em uma aula de história. Nessa aula, a tarefa proposta pelo professor era um estudo e elaboração de perguntas sobre a crise financeira de 1929 que seriam, depois de formuladas, trocadas entre as equipes da sala para serem respondidas. No Excerto 1 (o Anexo A contém uma descrição dos símbolos utilizados na transcrição dos excertos), Lucas, Arthur e João estão lendo um texto extraído de um portal de pesquisas da internet ${ }^{10}$ buscado por eles mesmos.

${ }^{10}$ GOMES, C. A crise 1929 (Grande Depressão). Disponível em:<http:/ / bit.ly/2pyDQsE/>. Acesso em: 10 out. 2015. 


\section{Excerto 1}

\begin{tabular}{|c|c|c|}
\hline 001 & & ((Lucas lê um texto para João)) \\
\hline 002 & Lucas & entendeu? (.) tipo pra não ficar \\
\hline 03 & & mui:to estoque o governo estava \\
\hline 04 & & compran: do e queiman:do as coisas (.) \\
\hline 05 & & ou então ele pagava para os carinhas \\
\hline 06 & & não produzi:r (.) que pra não ter \\
\hline 07 & & estoque \\
\hline 008 & Arthur & ) \\
\hline & João & (mas eu acho estranho) \\
\hline 10 & Arthur & eu acho que é- eu acho que é por causa do \\
\hline 11 & & plano que ele criou \\
\hline 012 & & $(1,0)$ \\
\hline 13 & João & :o (.) sim mas $(1,0)$ tipo como é \\
\hline 14 & & que de uma hora para outra foi \\
\hline 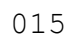 & & surgi:r \\
\hline 16 & Arthur & acho que é a administração né mano $(1,0)$ \\
\hline 7 & & [ó por que ele fala aqui ó]= \\
\hline 018 & Célia & [acho que esse texto pode ser \\
\hline 19 & & a introdução do que a gente \\
\hline 02 & & vai falar] \\
\hline 021 & & ((dirigindo-se à Taís e Laís)) \\
\hline 022 & Lucas & faz favor ((dirigindo-se para Célia)) \\
\hline 023 & Célia & Ah : : \\
\hline 024 & Arthur & =que $\circ$ texto lá disse ó que $\circ$ \\
\hline 025 & & estado passou a vigia:r o \\
\hline 026 & & mercado corrigir os investimentos e \\
\hline 027 & & fiscalizando as especulações tipo- \\
\hline 4 & & tipo \\
\hline 029 & João & mas: : $(1,0)$ mesmo assim \\
\hline 030 & Lucas & >Então não foi de uma hora para \\
\hline & & outra< \\
\hline
\end{tabular}

Lucas, assim que conclui a leitura do texto, orienta-se para João e faz uso de repertório próprio para produzir uma explicação sobre o que leu (linhas 002 a 007) e ajudar João a construir um entendimento acerca das 
informações necessárias para execução da tarefa proposta para a aula. Arthur também participa dessa atividade interacional (linhas 010 a 011; 016 a 017 e 024 a 028). Todavia, as explicações oferecidas por Lucas e Arthur não são suficientes para que João se convença, como fica marcado nos turnos (mas eu acho estranho) (linha 008), o (.) sim mas $(1,0)$ tipo como é que de uma hora para outra foi surgi:r (linhas 013 a 015) emas: : $(1,0)$ mesmo assim (linha 029).

A presença constante da adversativa "mas" nos turnos de João configura sua não concordância com as explicações oferecidas pelos colegas e também sinaliza a questão sobre a qual quer construir entendimento: como o governo estadunidense conseguiu recursos para reerguer a economia devastada na crise econômica de 1929.

Vale destacar nesta análise a presença de marcas de linguagem características da juventude nos turnos de Lucas e Arthur ao se apropriarem do conteúdo estudado para tentarem construir entendimento e avançar na tarefa da aula. Lucas usa, além do marcador discursivo "tipo" (linha 002), o termo "carinhas" (linha 006), referindo-se aos responsáveis pelo setor produtivo estadunidense da década de 1929. Arthur, para se dirigir a João, usa a expressão "né mano" (linha 016). Entendemos que ao usarem dessa linguagem engajados em tentar dar conta do objeto de aprendizagem emergente daquele ali e então e, ainda, orientados para o cumprimento da meta-fim da aula fazem ecoar suas identidades juvenis, evidenciando protagonismo no trabalho de fazer aprendizagem.

Outro ponto a ser destacado neste excerto é a ocorrência de aluno disciplinando aluno. Isso pode ser reconhecido quando Lucas (linha 022) chama atenção de Célia que falava de forma sobreposta a Arthur (linha 018). Essa ocorrência, também observada por Lopes (2015) e Rampton (2006), aponta para um engajamento em torno da meta-fim do encontro que é compartilhada. Isso significa que nesse contexto não apenas o professor é responsável por perseguir essa meta.

No Excerto 2, é Célia quem toma o turno para chamar atenção de Lucas, João e Arthur e assegurar que a tarefa proposta para a aula seja cumprida. 


\section{Excerto 2}

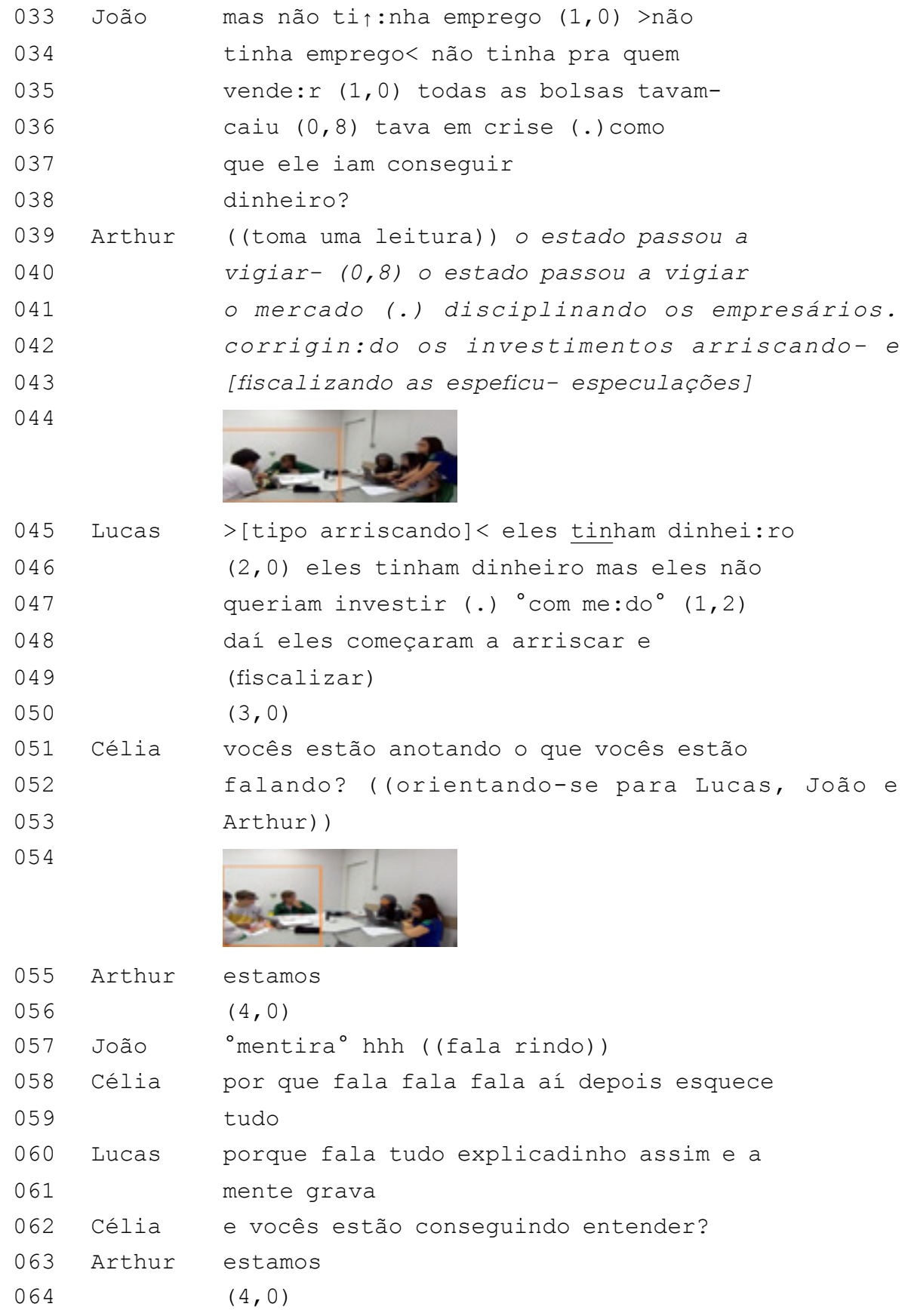


Célia interrompe a conversa de Lucas, Arthur e João, tomando o turno e orientando-se para eles a fim de verificar se estavam fazendo anotações sobre as discussões (linhas 051 a 053). Essa postura de Célia sinaliza sua preocupação em dar conta da tarefa proposta para a aula, inclusive enfatizando a necessidade de anotar as discussões, pois, segundo ela porque fala fala fala aí depois esquece tudo (linhas 058 e 059).

Lucas, Arthur e João, ao interagirem com Célia, defendem a conduta que vinham adotando no trabalho. Inicialmente Arthur diz a Célia que estão fazendo anotações (linha 055) e João o desmente (linha 057). Lucas, porém, argumenta que quando discutem detalhadamente a "mente grava" (linhas 060 a 061).

Todavia chama nossa atenção como, a partir da necessidade de cumprimento da tarefa proposta, um objeto de aprendizagem é legitimado como relevante na emergência e contingência da interação. Embora devendo cumprir com a tarefa proposta pelo professor de formular perguntas para troca com outras equipes, Lucas, João e Arthur continuam tentando produzir um entendimento que satisfaça João sobre como os Estados Unidos conseguiram dinheiro para se reerguer na crise de 1929 mesmo com dificuldades financeiras.

Fenômeno parecido foi analisado por Kanitz (2013) em um contexto de laboratório de desenvolvimento científico. Os dados desse contexto revelaram que, no curso das ações dos participantes, objetos de aprendizagem emergiam na forma de impasses, dúvidas etc.; e que alcançar entendimentos que resolvessem as questões e permitissem o retorno à atividade interrompida, envolvendo esforços interacionais dos participantes em torno dessa questão, consistia no trabalho de construir conhecimento em conjunto. Nesses termos é que entendemos que o objeto de aprendizagem que Lucas, Arthur e João tentam dar conta surge a partir da tarefa sugerida. Assim, a atividade de sala de aula aqui proposta e inserida no contexto institucional que analisamos oportuniza participação, engajamento e protagonismo dos estudantes no processo de aprendizagem.

No Excerto 3 apresentamos a sequência do empreendimento interacional dos participantes tentando dar conta do objeto de aprendizagem tornado relevante. 


\section{Excerto 3}

\begin{tabular}{|c|c|c|}
\hline 065 & João & ${ }^{\circ}$ eu ainda não entendi ${ }^{\circ}$ (.) como que surgiu \\
\hline 066 & & dinheiro \\
\hline 067 & Arthur & não não surgiu (.) o dinheiro é um moeda \\
\hline 068 & & monetária tá ligado? $(2,0)$ tipo (.) 0 \\
\hline 069 & & banco $(7,0)$ ó (.) o banco (.) se não me \\
\hline 070 & & engano foi o banco (.) tá ligado (.) eu \\
\hline 071 & & esqueci o nome do processo ( \\
\hline 072 & Lucas & ( \\
\hline 073 & Arthur & ( \\
\hline 074 & João & hhhhhhh eu não quero saber de onde (.) \\
\hline 075 & & surgiu o dinheiro eu quero saber como que \\
\hline 076 & & eles tinham \\
\hline 077 & Lucas & por que não adianta o banco produzir um \\
\hline 078 & & monte de >nota nota nota nota< que eles \\
\hline 079 & & não vão ter dinheiro \\
\hline 080 & & $(3,0)$ \\
\hline 081 & Arthur & (tipo ó (.) >por exemplo< (.)) tipo você é \\
\hline 082 & & o: : proprietário da terra e eu sou o \\
\hline 083 & & estado você me dá um pedaço da: : \\
\hline 084 & & $(2,0)$ \\
\hline 085 & João & ${ }^{\circ} \mathrm{não}(.) \mathrm{mas}^{\circ}$ \\
\hline 086 & Lucas & ${ }^{\circ}$ escambo ${ }^{\circ}$ \\
\hline 087 & Arthur & tipo (.) eles faziam troca de mercadoria \\
\hline 088 & João & não (.) mas- eu quero saber como que eles \\
\hline 089 & & conseguiam o dinheiro \\
\hline 090 & Arthur & como que eles conseguiam dinh[ei:ro para] \\
\hline 091 & João & [é: : para] \\
\hline 092 & Lucas & construir as obras públicas, habitações, \\
\hline 093 & & comunidades, irrigação escolas construções \\
\hline 094 & & edificações escolas ( \\
\hline 095 & João & Professo::r (.) ((chamando o professor) ) \\
\hline 096 & Lucas & ah^ agora entendi o que ele está querendo \\
\hline 09 & & dizer \\
\hline 098 & & $\{14,0$ de transcrição impossível $\}$ \\
\hline
\end{tabular}




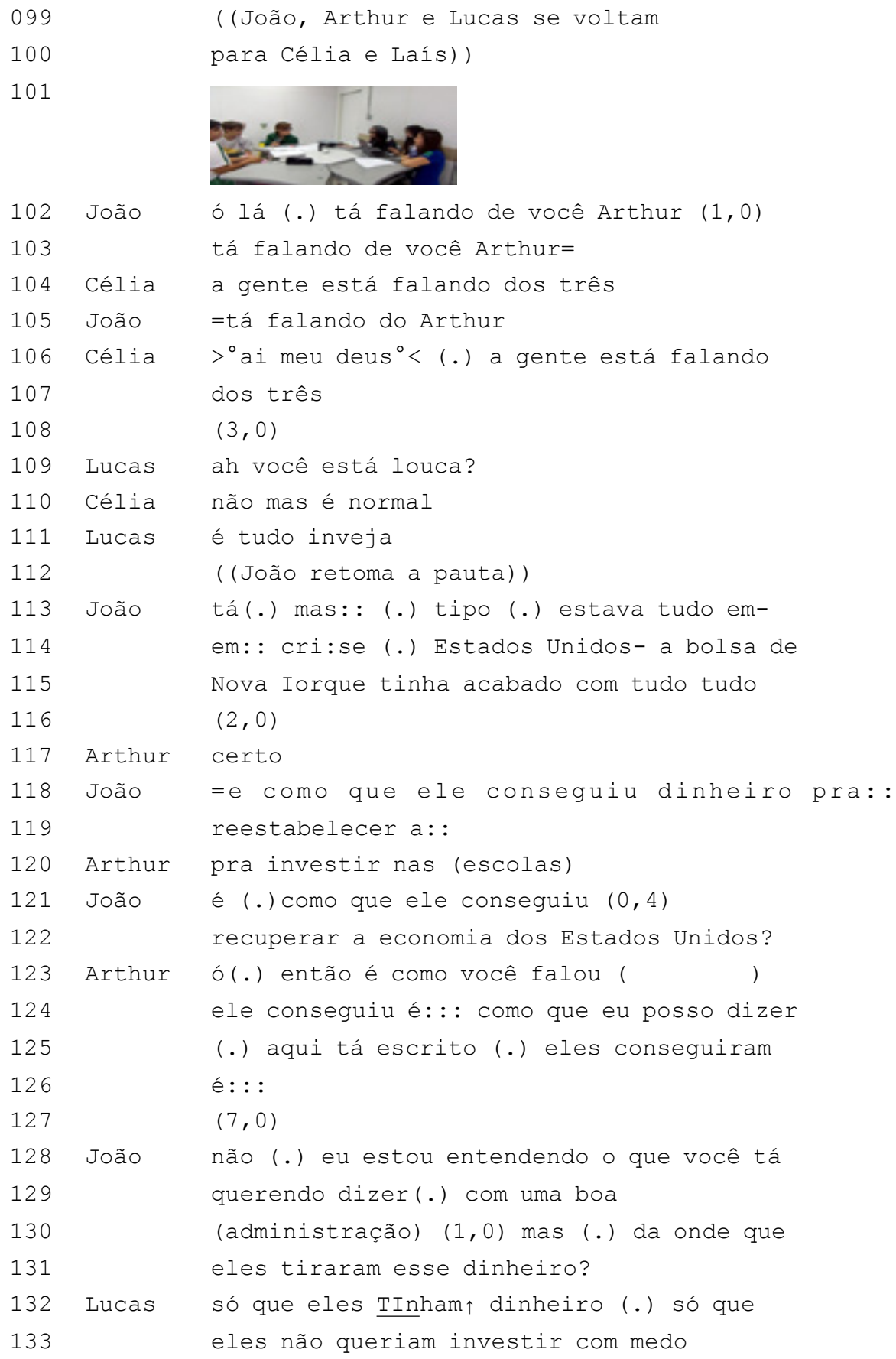




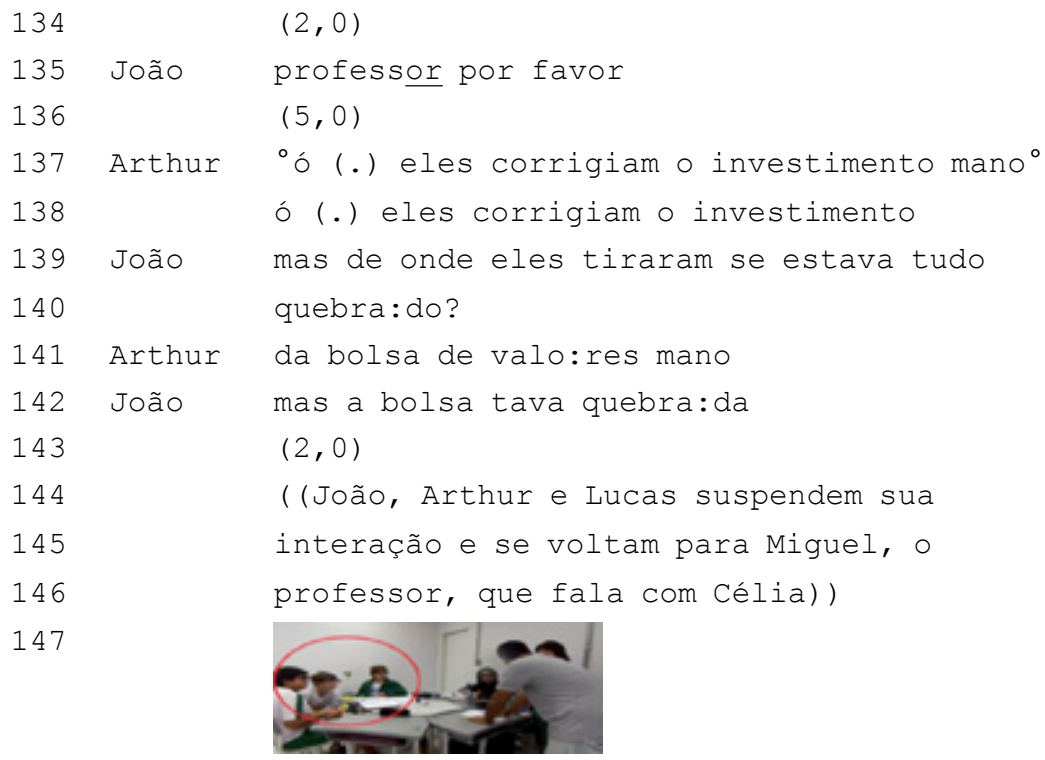

João, Lucas e Arthur, conforme se nota na sequência interacional transcrita no Excerto 3, envidam esforços para lidar com o objeto de aprendizagem emergente e contingente do aqui-e-agora. Todavia, é possível perceber que nem Lucas nem Arthur têm suas explicações aceitas por João como suficientes, por isso o entendimento não é construído. Dessa forma, os participantes recorrem a Miguel, o professor, a fim de que ele os auxilie.

No Excerto 4, Miguel passa a participar da atividade interacional empreendida pelos participantes.

Excerto 4

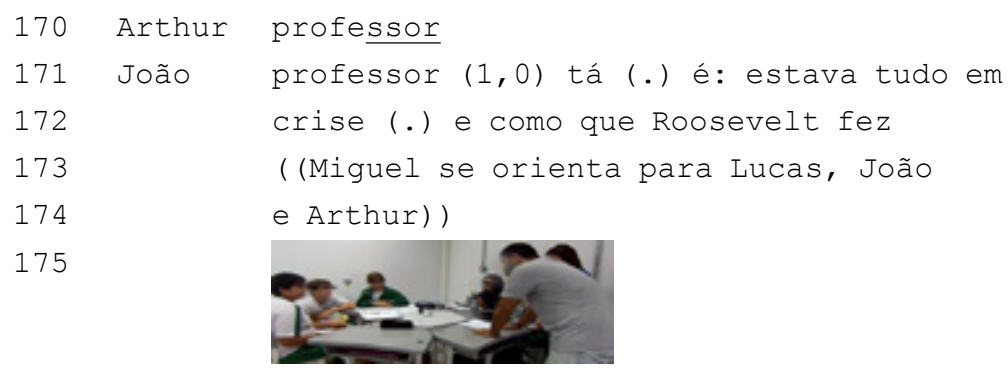

176 Arthur quando ele estava na presidência como que 177 ele [conseguiu (.) dinheiro] 
178 João [conseguiu (.) dinheiro] pra fazer todas

179 aquelas mudanças?

180 Miguel ah me respondam vocês

181 João [hhhhhh]

182 Lucas [hhhhhh]

183 Arthur [hhhhhh] (.) será que é por conta do- da

184 boa administração do estado?

185 João não é por que aqui fala da boa

186 administração (.) mas é: estava tudo em

187 cri:se (.) não tinha onde ele investi:r(.)

188 como ele conseguiu [esse dinheiro]?

189 Miguel [não] (.) o: estado: por mais que ele

190 esteja em cri:se ele consegue: $(0,7)$

191 recursos $(1,0)$ tem da onde tirar recursos

$192 \quad(1,0)$ né (.) impo: :stos é: : : :

193 Arthur e eles conseguiram é: $(2,0)$ meio que

$194 \quad(2,0)$ aumentar o valor na bolsa de

$195 \quad$ valores

196 Miguel hhhh é ((fala rindo))

197 João mas a bolsa estava quebrada

198 Miguel mas qual que é a principal medi:da como

199 que o que o: : Roosevelt lá (.) através do

200 new deal (.) como que ele reaquece a

$201 \quad$ economia?

202

203

204

( Arthur, Lucas e João buscam resposta para pergunta de Miguel em um texto))

Arthur

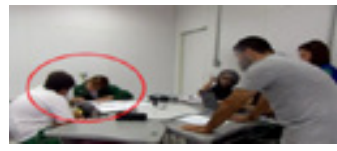

206

207 Miguel Roosevelt

208

209

$(2,0)$

210 Miguel

aqui ó (.) ele passou a vigiar o mercado

então(.) controlar o mercado $(0,4)$

controlar a economia (.) então esse é um produto $(1,0)$ 


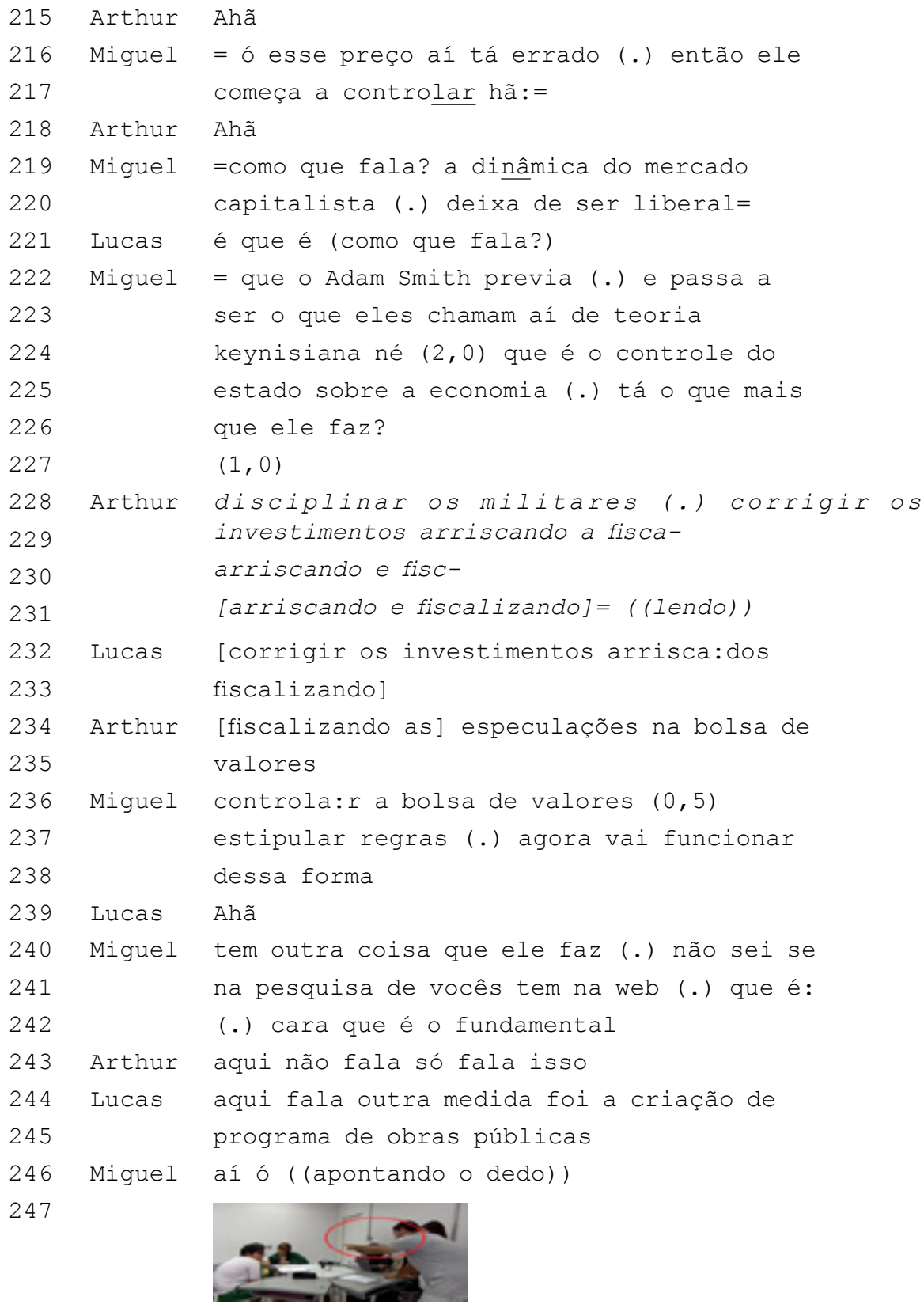

248 Arthur ah: sim 


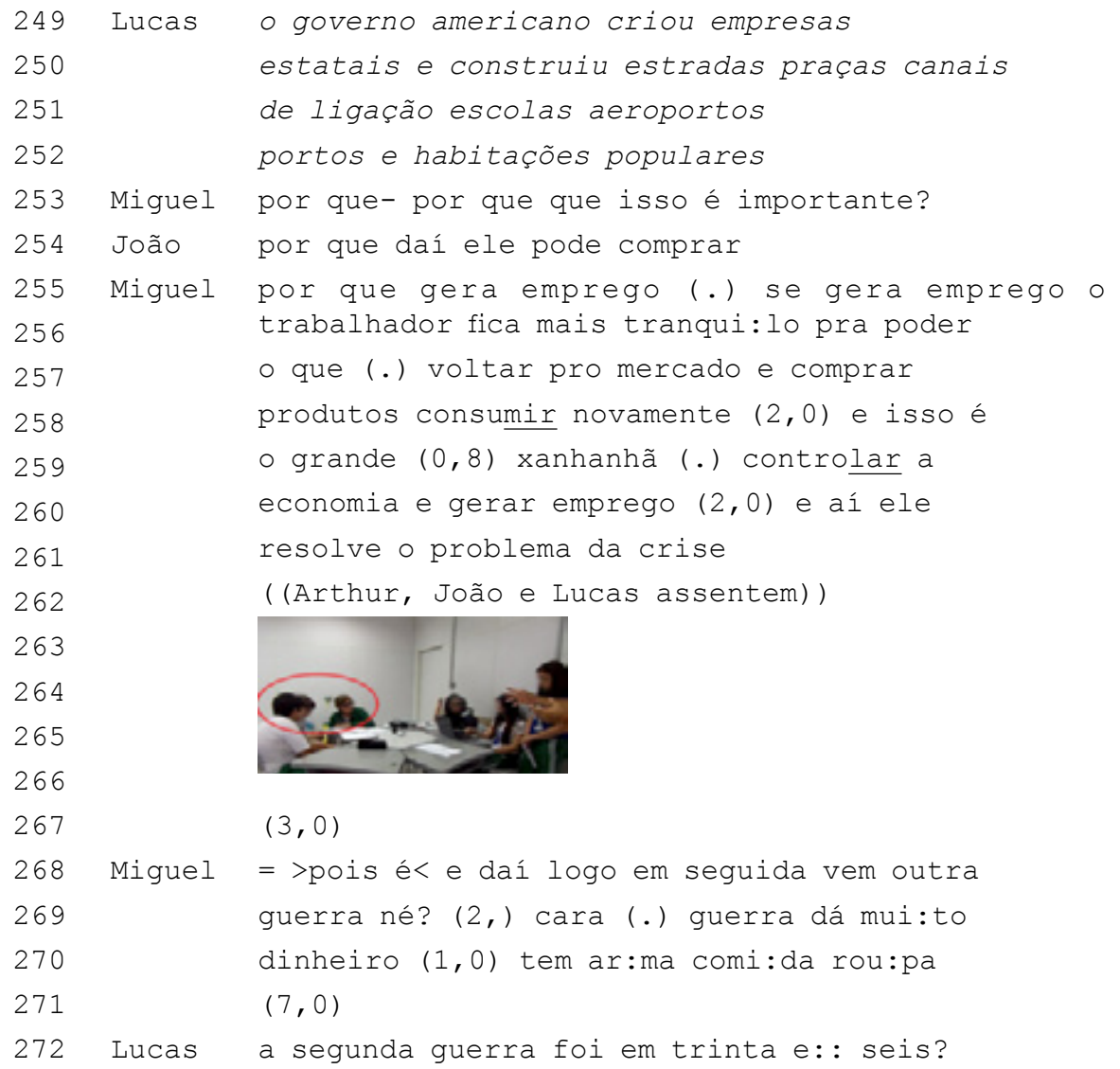

Após ser questionado por João e Arthur sobre como os Estados Unidos conseguiram dinheiro para se reerguerem na crise de 1929 (linhas 170 a 179), Miguel toma o turno (linha 180) e não oferece resposta direta aos alunos, mas devolve a questão dizendo ah me respondam vocês. $\mathrm{Na}$ sequência do excerto, os turnos de Miguel nos chamam atenção, pois eles não são respostas prontas às perguntas dos alunos, mas sim formulações que aparentemente conduzem os alunos à construção conjunta de um entendimento. Selecionamos três recortes do Excerto 4 em que há turnos de Miguel a fim de explicar e exemplificar essa asserção.

No primeiro, discutimos a relação menos assimétrica entre papéis institucionais de professor e alunos coconstruída no contexto; no segundo, demonstramos que Miguel ratifica o objeto de aprendizagem com que lidam os alunos e, como dissemos, não oferece respostas prontas, mas constrói reflexões conjuntas; por fim, no terceiro, apresentamos como os participantes conseguem dar cabo do objeto de aprendizagem. 
Recorte 1 - Excerto 4

$\begin{array}{lll}183 & \text { Arthur } & \text { [hhhhh] (.) será que é por conta do- da } \\ 184 & \text { boa administração do estado? } \\ 185 & \text { João } & \text { não é por que aqui fala da boa } \\ 186 & & \text { administração (.) mas é: estava tudo em } \\ 187 & \text { cri:se (.) não tinha onde ele investi:r(.) } \\ 188 & \text { como ele conseguiu [esse dinheiro]? } \\ 189 & \text { Miguel } & \text { [não] (.) o: estado: por mais que ele } \\ 190 & & \text { esteja em cri:se ele consegue: (0,7) } \\ 191 & & \text { recursos (1,0) tem da onde tirar recursos } \\ 192 & & (1,0) \text { né (.) impo: stos é:: : } \\ 193 & \text { Arthur eles conseguiram é: (2,0) meio que } \\ 194 & \text { (2,0) aumentar o valor na bolsa de } \\ 195 & \text { valores }\end{array}$

Neste primeiro recorte retomado do Excerto 4, Arthur responde ao turno anterior de Miguel (linha 180) com uma nova pergunta: [hhhhhh] (.) será que é por conta do- da boa administração do estado? (linhas 183 e 184). Embora não tendo selecionado o próximo falante, a pergunta formulada por Arthur tem a intenção de receber uma confirmação que, em um contexto de sala de aula convencional seria oferecida pelo professor que, em geral, é sempre o próximo a tomar o turno. Todavia, João se autosseleciona e responde à questão de Arthur, deixando uma outra pergunta a ser respondida sem selecionar o próximo falante: mas é: estava tudo em cri:se (.) não tinha onde ele investi:r (.) como ele conseguiu [esse dinheiro]? (linhas 186 a 188). Miguel é o próximo a tomar o turno e oferece a contribuição para lidar com o objeto de aprendizagem em questão (linhas 189 a 192). Arthur, autosselecionando-se para tomar o turno, demonstra estar atento à explicação de Miguel a ponto de completar sua informação (linhas 193 a 195).

Reconhecemos, a partir da fala-em-interação demonstrada neste recorte, que no contexto analisado há uma relação menos assimétrica entre professor e alunos. A negociação das identidades institucionais de professor/ aluno aparentemente está mais associada a outras espécies de relações, como a de saber; do que a relações de poder e controle social institucionalmente predeterminadas, como ocorre na IRA. 
Recorte 2 - Excerto 4

\begin{tabular}{|c|c|c|}
\hline 197 & João & mas a bolsa estava quebrada \\
\hline 198 & \multirow[t]{7}{*}{ Miguel } & mas qual que é a principal medi:da como \\
\hline 99 & & que o que o: : Roosevelt lá (.) através do \\
\hline 00 & & new deal (.) como que ele reaquece a \\
\hline 01 & & economia? \\
\hline 02 & & ( (Arthur, Lucas e João buscam resposta \\
\hline & & para pergunta de Miguel em um texto)) \\
\hline & & \\
\hline 05 & \multirow[t]{2}{*}{ Arthur } & aqui fala medida pro- (.) como que fala? \\
\hline 06 & & $(1,0)$ \\
\hline & \multirow[t]{2}{*}{ Miguel } & Roosevelt \\
\hline & & $(2,0)$ \\
\hline 209 & Arthur & aqui ó (.) ele passou a vigiar o mercado \\
\hline & \multirow[t]{5}{*}{ Miguel } & então(.) controlar o mercado $(0,4)$ \\
\hline & & controlar a economia (.) então esse é um \\
\hline & & ponto (.) ó então você não pode fazer \\
\hline & & fusão (.) você não pode vender esse \\
\hline & & produto $(1,0)$ \\
\hline
\end{tabular}

Neste recorte, como amostra de outras ocorrências ao longo do excerto, em dois turnos mais longos (linhas 198 a 201 e linhas 210 a 214), Miguel produz reflexões sobre o conteúdo em questão sem, contudo, responder diretamente às perguntas dos alunos. Essas participações de Miguel, instigando os alunos a construírem juntos um entendimento, estão arraigadas na proposta pedagógica do Colégio Empreendedor: desenvolver um trabalho conjunto de alunos e professores a fim de darem conta de desafios de aprendizagem.

É importante ainda mencionar que Miguel ratifica o objeto de aprendizagem em torno do qual os alunos produzem ação social. Em outras palavras, Miguel não deslegitima o trabalho interacional de João, Arthur e Lucas por conta de não estarem necessariamente executando a tarefa da aula, formulando questões e as anotando para posteriormente trocar entre as equipes. Isso fica evidenciado na sequencialidade dos turnos de fala, já que os turnos de Miguel levam em consideração o conteúdo do turno anterior. Dessa forma, o entendimento necessário para dar conta do objeto de aprendizagem em questão vai sendo construído conjuntamente na fala-em-interação. 
No recorte a seguir, os participantes conseguem chegar conjuntamente a esse entendimento satisfatório com a ajuda de Miguel.

\section{Recorte 3 - Excerto 4}

240 Miguel tem outra coisa que ele faz (.) não sei se 241 na pesquisa de vocês tem na web (.) que é:

242 (.) cara que é o fundamental

243 Arthur aqui não fala só fala isso

244 Lucas aqui fala outra medida foi a criação de

245 programa de obras públicas

246 Miguel aí ó ((apontando o dedo))

247

248

249

250

251

252

253

254

255

256

257

258

259

260

261

262

263

264

265

266



Arthur ah: sim

Lucas o governo americano criou empresas estatais e construiu estradas praças canais de ligação escolas aeroportos portos e habitações populares

Miguel por que-por que que isso é importante?

João por que daí ele pode comprar

Miguel por que gera emprego (.) se gera emprego o trabalhador fica mais tranqui:lo pra poder

o que (.) voltar pro mercado e comprar produtos consumir novamente $(2,0)$ e isso é - grande $(0,8)$ xanhanhã (.) controlar a economia e gerar emprego $(2,0)$ e aí ele resolve o problema da crise ((Arthur, João e Lucas assentem)) 
Miguel, conforme demonstramos, não oferece respostas prontas às perguntas feitas pelos alunos João, Lucas e Arthur, mas prefere construir entendimento conjunto, permitindo que os alunos opinem e manifestem seus entendimentos. Todavia, avançando na construção conjunta do entendimento que poderia dar conta do objeto de aprendizagem para o qual os alunos estavam orientados e se engajam interacionalmente, Miguel aponta para outro fator que, para ele, seria fundamental para compreensão da questão, sem, contudo, dizer de imediato o que era: tem outra coisa que ele faz (.) não sei se na pesquisa de vocês tem na web (.) que é: (.) cara que é o fundamental (linhas 240 a 242).

Lucas, entre as linhas 244 e 245 , toma o turno para responder ao questionamento de Miguel a partir de um achado no texto que liam: aqui fala outra medida foi a criação de programa de obras públi cas. Diante dessa resposta, Miguel exclama aí ó (linha 246) e aponta o dedo (linha 247), demonstrando tanto com sua fala quanto com seu gesto corporal que aquela era a informação essencial que daria conta da questão que tentavam responder.

Assim, após Arthur demonstrar que havia compreendido (linha 248), Lucas se autosseleciona e lê o trecho do texto que tinha em mãos que dava mais detalhes sobre a informação (linhas 249 a 252). Miguel, então, formula nova pergunta para os alunos por que- por que que isso é importante? (linha 253) para verificar sua compreensão. Essa pergunta é respondida por João (linha 254), demonstrando seu entendimento sobre a informação. Essa resposta é ratificada por Miguel, que assume o turno completando a informação de João (linha 255) e oferece explicações extras sobre a importância do programa de obras públicas para recuperação da economia estadunidense durante a crise de 1929. Arthur, João e Lucas assentem (linha 263), demonstrando entendimento das explicações de Miguel e, assim, fechando a construção conjunta de um entendimento necessário para dar cabo do objeto de aprendizagem.

Em síntese, a atividade interacional transcrita neste dado evidencia os seguintes momentos: i) ratificação de um objeto de aprendizagem emergente e contingente na fala-em-interação - como os Estados Unidos conseguiram dinheiro para se reerguer na crise econômica de 1929; ii) participação e engajamento na produção de ação social tentando dar conta desse objeto legitimado no curso da atividade interacional; iii) participação de Miguel, a partir de convite dos alunos, pois não conseguem chegar a uma resposta satisfatória; iv) 
ratificação de Miguel do objeto de aprendizagem com que lidam os alunos, construindo entendimento satisfatório para a questão sem, contudo, dar respostas prontas; v) protagonismo dos alunos, pois conseguem dar cabo do objeto de aprendizagem, envidando esforços conjuntos na construção de um entendimento satisfatório - o programa de obras públicas adotado pelo governo estadunidense foi fundamental para recuperação da economia durante a crise de 1929, pois gerou emprego e renda para os trabalhadores.

\section{Considerações finais}

O dado de fala-em-interação analisado aponta para uma forma de organização não canônica, isto é, sem a "regência" e "controle social" exclusivos do professor, pois a negociação de manutenção de uma pauta é compartilhada entre os participantes. Desse modo, as oportunidades de participação nesse cenário são ampliadas, criando um contexto em que as relações interacionais são menos assimétricas e mais democráticas de forma que a negociação das identidades institucionais de professor e aluno é constante e está, aparentemente, mais ligada a uma relação de saberes legitimados do que de autoridade pré-determinada institucionalmente.

Além disso, reconhecemos que, nesse contexto, a maior liberdade para autosseleção e participação, legitimação de um objeto de aprendizagem emergente da interação (inclusive pelo professor), possibilidade para manifestação da identidade juvenil e engajamento interacional para dar conta do objeto de aprendizagem legitimado são índices de uma nova ordem comunicativa de sala de aula que possibilita agentividade e protagonismo dos estudantes, de forma que possam experienciar situações legítimas de construção de conhecimento em que identificam problemas, levantam e testam hipóteses e constroem conjuntamente entendimentos satisfatórios.

Por fim, no intuito de estabelecer uma interlocução pedagógica a partir de nossos resultados destacamos que na sala de aula contemporânea ocorre aprendizagem por meio de participações diferentes daquelas tradicionalmente esperadas na escola. O professor deixou de ser o único protagonista do ensino escolar, por isso há necessidade de reconhecer e legitimar o protagonismo do aluno e dessa forma os modos de organização das salas de aula precisam ser revistos, sobretudo no que tange a aspectos de fala-em-interação. Além disso, é necessário destinar mais atenção à aprendizagem (STREET, 2014) e não só ao ensino em nossas políticas educacionais e nos cursos de formação de professores. E esse deslocamento 
de foco implica reconhecer que nas nossas salas de aula contemporâneas, conforme observado em Lopes (2015), Rampton (2006) e neste artigo, há alunos engajados e que protagonizam o trabalho de fazer aprendizagem por meio de práticas de linguagem como as participações exuberantes, sobrevivendo, assim, às contingências da modernidade tardia (RAMPTON, 2006).

\section{Referências}

ABELEDO, M. L. Uma compreensão etnográfica da aprendizagem de língua estrangeira na fala-em-interação de sala de aula. 2008. 217f. Tese (Doutorado em Letras) - Programa de Pós-Graduação em Letras, Universidade Federal do Rio Grande do Sul, Porto Alegre, 2008.

BLOMMAERT, J.; RAMPTON, B. Language and superdiversity. Diversities, v. 13, n. 2, p. 1-21, 2011.

CAZDEN, C. B. Classroom discourse: the language of teaching and learning. Portsmouth: Heinemann, 2001.

CANAGARAJAH, S. Translingual practice: Global Englishes and cosmopolitan relations. New York: Routledge, 2012.

CLARK, H. O uso da linguagem. Cadernos de Tradução, Porto Alegre, v.9, p. 49-71, 2000.

CONCEIÇÃO, L. E.; GARCEZ, P. M. O revozeamento no discurso da escola pública cidadã. Intercâmbio, São Paulo, v.14, p. 1-10, 2005.

CORONA, M. D. C. Fala-em-interação cotidiana e fala-em-interação institucional: uma análise de audiências criminais. In: LODER, L. L.; JUNG, N. M. (Org.). Análises de fala-em-interação institucional: a perspectiva da Análise da Conversa Etnometodológica. Campinas: Mercado de Letras, 2009. p.13-44.

DAYRELL, J. O jovem como sujeito social. Revista Brasileira de Educação, Rio de Janeiro, n.24, p. 40-52, set./dez.2003.

DREW, P.; HERITAGE, J. Analyzing talk at work: an introduction. In: DREW, P.; HERITAGE, J. (Org.). Talk at work: Interaction in institutional settings. Cambridge: Cambridge University Press, 1992. p. 3-65.

ERICKSON, F.; SHULTZ, J. O quando de um contexto: questões e métodos na análise da competência social. In: RIBEIRO, B. T.; GARCEZ, P. M. Sociolinguística interacional. São Paulo: Loyola, 2013. p. 215-234.

FERRETTI, C. J.; ZIBAS, D. M. L.; TARTUCE, G. L. B. P. Protagonismo juvenil na literatura especializada e na reforma do ensino médio. Cadernos de Pesquisa, vol.34, n.122, p. 411-423, 2004. https://doi.org/10.1590/S0100-15742004000200007 
GAGO, P. C. Questões de transcrição em Análise da Conversa. Veredas, Juiz de Fora, v.6, n.2, p.89-113, jul./dez. 2002.

GARCEZ, P. M. A organização da fala-em-interação social: controle social, reprodução de conhecimento, construção conjunta de conhecimento. Calidoscópio, São Leopoldo, v.4, n.1, p.66-80, jan./abr.2006.

GARCEZ, P. M. A perspectivada Análise da Conversa Etnometodológica sobre o uso da linguagem em interação social. In: LODER, L. L.; JUNG, N. M. (Org.). Falaem-interação social: introdução à Análise da Conversa Etnometodológica. Campinas: Mercado de Letras, 2008a. p. 17-38.

GARCEZ, P. M. Microethnography in the classroom. In: HORNBERGER, N. H. (Ed.). Encyclopedia of language and education.Vol. 10. Berlim: Springer, 2008b. p. 257-272. https://doi.org/10.1007/978-0-387-30424-3_259

GARCEZ, P. M. A fala-em-interação de sala de aula: controle social, reprodução, construção conjunta. In: GUEDES, P. C. (Org.). Educação Linguística e cidadania. Porto Alegre: Editora da UFRGS, 2012. p. 87-121.

GARCEZ, P. M.; BULLA, G. S.; LODER, L. L. Práticas de pesquisa microetnográfica: geração, segmentação e transcrição de dados audiovisuais como procedimentos analíticos plenos. DELTA, São Paulo, v. 30, n. 2, p. 257-288, 2014. https://doi.org/10.1590/0102-445078307364908145

GOFFMAN, E. Footing. In: RIBEIRO, B. T.; GARCEZ, P.M. (Org.).Sociolinguistica interacional. São Paulo: Loyola, 2013 [1981]. p.107-148.

GUMPERZ, J. Convenções de contextualização. In: RIBEIRO, B. T.; GARCEZ, P. M. (Org.). Sociolinguistica interacional. São Paulo: Loyola, 2013 [1982]. p.149-182.

JUNG, N. M. A reprodução de identidades sociais na comunidade e na escola. Ponta Grossa: Editora UEPG, 2009.

KANITZ, A. Resolução de problemas e construção conjunta de conhecimento na fala-eminteração em cenário de desenvolvimento tecnológico. 2013. 184f. Dissertação (Mestrado em Linguística) - Universidade Federal do Rio Grande do Sul, Porto Alegre, 2013.

LODER, L. L.; JUNG, N. M. (Org.). Fala-em-interação social: introdução à Análise da Conversa Etnometodológica. Campinas: Mercado de Letras, 2008.

LODER, L. L.; JUNG, N. M. (Org.).Análises de fala-em-interação institucional: a perspectiva da Análise da Conversa Etnometodológica. Campinas: Mercado de Letras, 2009.

LODER, L. L. O modelo Jefferson de transcrição: convenções e debates. In: LODER, L. L.; JUNG, N. M. (Org.).Fala-em-interação social: introdução à Análise da Conversa Etnometodológica. Campinas: Mercado de Letras, 2008. p. 127-161. LOPES, M. F. R. A fala-em-interação de sala de aula contemporânea no Ensino Médio: o trabalho de fazer aula e fazer aprendizagem de língua espanhola. 2015.197f. Tese 
(Doutorado em Letras) - Universidade Federal do Rio Grande do Sul, Porto Alegre, 2015.

LUCENA, M. I. P. Práticas de linguagem na realidade da sala de aula: contribuições da pesquisa de cunho etnográfico em Linguística Aplicada. DELTA, São Paulo, v. 31, n. especial, p. 67-95, 2015.

MARKEE, N.; KASPER, G. Classroom talks: an introduction. The Modern Language Journal, Madison, v. 88, n. 4, p. 491-500, 2004. https://doi. org/10.1111/j.0026-7902.2004.t01-14-.x

O'CONNOR, M. C.; MICHAELS, S. Shifting Participant Frameworks: orchestrating thinking practices in group discussion. In: HICKS, D. (Org.). Discourse, learning and schooling. Cambridge: Cambridge University Press, 1996. p. 63-103. https://doi.org/10.1017/CBO9780511720390.003

PETERMANN, R. A fala-em-interação em sala de aula de ensino médio: participação e construção conjunta de conhecimento em uma equipe de trabalho. 2016.138f. Dissertação (Mestrado em Letras) - Universidade Estadual de Maringá, Maringá, 2016.

RAMPTON, B. Language in late modernity: Interaction in an urban school. Cambridge: Cambridge University Press, 2006. https:/ / doi.org/10.1017/CBO9780511486722 SACKS, H.; SCHEGLOFF, E. A.; JEFFERSON, G. Sistemática elementar para a organização da tomada de turnos para a conversa. Veredas, Juiz de Fora, v.7, n.1-2, p.9-73, 2003.

SCHULZ, L. A construção da participação na fala-em-interação de sala de aula: um estudo microetnográfico sobre a participação em uma escola municipal de Porto Alegre. 2007. 163f. Dissertação (Mestrado em Letras) - Programa de Pós-Graduação em Letras, Universidade Federal do Rio Grande do Sul, Porto Alegre, 2007.

STREET, B. Letramentos sociais: Abordagens críticas do letramento no desenvolvimento, na etnografia e na educação.São Paulo: Parábola, 2014.

UFLACKER, C. Fazer avaliar na construção do participante competente em sala de aula. 2012. 223f. Tese (Doutorado em Letras) - Programa de Pós-Graduação em Letras, Universidade Federal do Rio Grande do Sul, Porto Alegre, 2012.

WARING, H. Z. Using explicit positive assessment in the language classroom: IRF, feedback, and learning opportunities. The Modern Language Journal, Hoboken, v.92, n.4, p.577-594, 2008. https://doi.org/10.1111/j.1540-4781.2008.00788.x

Data de submissão: 30/12/2016. Data de aprovação: 18/04/2017. 
ANEXO A - Convenções de transcrição

\begin{tabular}{|c|c|c|}
\hline - & (ponto final) & Entonação descendente \\
\hline ? & (ponto de interrogação) & Entonação ascendente \\
\hline ' & (virgula) & Entonação de continuidade \\
\hline- & (hífen) & Marca de corte abrupto \\
\hline$\uparrow \downarrow$ & $\begin{array}{c}\text { (flechas para cima e para } \\
\text { baixo) }\end{array}$ & $\begin{array}{l}\text { Alteração do tom de voz. } \\
\text { Mais agudo: para cima; } \\
\text { mais grave para baixo }\end{array}$ \\
\hline paLavra & (sublinhado) & Som enfatizado \\
\hline$\overline{\text { PALAVRA }}$ & (maiúsculas) & Fala em volume alto \\
\hline palavra $^{\circ}$ & (sinais de graus) & Fala em voz baixa \\
\hline${ }^{0}$ palavra ${ }^{\circ}$ & $\begin{array}{l}\text { (sinais de graus } \\
\text { duplos) }\end{array}$ & $\begin{array}{c}\text { Fala em voz destacadamente } \\
\text { mais baixa. }\end{array}$ \\
\hline$>$ paLavra< & $\begin{array}{c}\text { (sinais de maior do que } \\
\text { e menor do que) }\end{array}$ & Fala acelerada \\
\hline$<$ palavra> & $\begin{array}{c}\text { (sinais de menos do que } \\
\text { e maior do que) }\end{array}$ & Fala desacelerada \\
\hline hh & (série de h's) & Aspiração ou riso \\
\hline . hh & (h's precedidos de & Inspiração audível \\
\hline ] & (colchetes) & $\begin{array}{c}\text { Fala simultânea ou } \\
\text { sobreposta }\end{array}$ \\
\hline$=$ & (sinal de igual) & Elocuções contíguas \\
\hline$(2,4)$ & $\begin{array}{l}\text { (números entre } \\
\text { parênteses) }\end{array}$ & $\begin{array}{l}\text { Medida de silêncio (em } \\
\text { segundos e décimos de } \\
\text { segundos) }\end{array}$ \\
\hline$()$. & $\begin{array}{l}\text { (ponto entre } \\
\text { parênteses) }\end{array}$ & $\begin{array}{l}\text { Micropausa, até } 2 / 10 \text { de } \\
\text { segundo }\end{array}$ \\
\hline ( ) & (parênteses vazios) & $\begin{array}{l}\text { Segmento de fala que não } \\
\text { pode ser transcrito }\end{array}$ \\
\hline (palavra) & $\begin{array}{c}\text { (segmento de fala entre } \\
\text { parênteses) }\end{array}$ & Transcrição duvidosa \\
\hline $\begin{array}{l}\text { (( deixando } \\
\text { o texto ) ) }\end{array}$ & (parênteses duplos) & $\begin{array}{c}\text { Descrição de atividade não } \\
\text { vocal }\end{array}$ \\
\hline De domingo & (segmento em itálico) & $\begin{array}{c}\text { Reprodução de leitura em } \\
\text { voz alta }\end{array}$ \\
\hline $\begin{array}{l}\text { \{transcrição } \\
\text { impossível }\end{array}$ & (chaves duplas) & $\begin{array}{c}\text { Explicação de uma omissão } \\
\text { de transcrição ou outra } \\
\text { explicação necessária. }\end{array}$ \\
\hline & (círculo vermelho) & $\begin{array}{c}\text { Enfase em um participante, } \\
\text { movimento ou parte do } \\
\text { quadro de imagem. }\end{array}$ \\
\hline & (quadro laranja) & $\begin{array}{c}\text { Destaque para um piso } \\
\text { conversacional. }\end{array}$ \\
\hline
\end{tabular}

Fonte: Adaptado de Loder (2008). 